\title{
The Influence of Team Demographic Composition on Individual Helping Behavior
}

\author{
Igor Kotlyar $^{1}$, Leonard Karakowsky ${ }^{2}$ \\ ${ }^{1}$ Faculty of Business and Information Technology, University of Ontario Institute of Technology, \\ Oshawa, Canada \\ ${ }^{2}$ School of Administrative Studies York University, Toronto, Canada \\ Email:1karakow@yorku.ca
}

Received September 29 ${ }^{\text {th }}, 2012$; revised October $31^{\text {st }}, 2012$; accepted November $27^{\text {th }}, 2012$

\begin{abstract}
The aim of our laboratory study was to examine how the demographic composition (in terms of gender and culture) of work teams can influence levels of helping behavior demonstrated among group members. Participants included 216 university students from undergraduate business programs in two large North American universities (108 men, 108 women) who were randomly assigned to small groups for the purpose of engaging in business case discussions. Discussions were videotaped in order to observe helping behavior among individuals. Our findings indicated that the numerical minority member (measured in terms of gender or ethnicity) was less likely to engage in the helping activity. These findings suggest that the effects of numerical minority status are not confined to task-performance related behaviors like participation and emergent leadership, but also influence behaviors that involve how members relate to one and other, and whether they engage in helping behavior.
\end{abstract}

Keywords: Helping Behaviour; Gender; Ethnicity; Groups

\section{Introduction}

The influence of demographic diversity on the behavior of group members has been a topic of interest and controversy for a number of years. Organizational demography researchers have long been concerned with the effect of gender and cultural diversity on behavior, group processes, and team performance. With the advancement of women in organizations and a trend toward globalization, more studies have been focusing on the impact of demographic differences on business practices and outcomes (e.g., Chou \& Pearson, 2011; Davis, Babakus, Englis, \& Pett, 2010; Gilbert, Burnett, Phau, \& Haar, 2010; Lauring \& Selmer, 2011; Mahadeo, Soobaroyen, \& Hanuman, 2012).

Given the growth of demographically diverse teams, it is important to understand how demographic composition can impact helping behavior (c.f., Van der Vegt \& Van de Vliert, 2005). It has been observed that the effectiveness of work teams depends on whether members help each other to fulfill their tasks and solve problems (Holland, Gaston, \& Gomez, 2000). Research has demonstrated that there are attitudinal and behavioral consequences for members of diverse groups (e.g., Coon \& Kemmelmeier, 2001; Jones \& Schaubroeck, 2004; Kirkman, Tesluk, \& Rosen, 2004; Steers \& Sanchez-Runde, 2002), and a number of studies have specifically investigated demographic differences, including gender and culture, as potential antecedents of helping behaviors (e.g., Farrell \& Finkelstein, 2007; Kwantes, 2003; Lin \& Ho, 2010).

Despite the available research, several gaps remain with respect to the existing knowledge of how gender and culture diversity affects individual helping behavior in demographically diverse teams. First, research has tended to focus on the implications of group diversity at the group and organizational level outcomes, and has not fully addressed issues related to individ- ual member behavior. Second, while it has been demonstrated that individual's gender and culture can affect their helping behaviors, the results have been inconsistent and the nature of the actual impact remains unclear. Third, while research has attempted to examine the direct effect of a person's gender and culture on helping behavior, and in doing so, ironically, it has overlooked the effects of group demographic composition in diverse groups. This is a major omission, because differences in group member behavior may be more than simply a product of underlying gender or culture, but can also stem from the demographic composition of the group itself. The aim of our study, reported below, was to attempt to address those gaps. This study examined within an experimental setting, the influence of group demographic diversity on helping behavior of individual group members.

\section{Proportional Representation and Helping Behavior in Team Contexts}

Organizational citizenship behavior facilitates the accomplishment of organizational goals and increases group and organizational effectiveness (George \& Bettenhausen, 1990; Organ, 1988, 1990; Podsakoff, Whiting, Podsakoff, \& Blume, 2009). Organ $(1988,1990)$ proposed several dimensions of organizational citizenship behavior, including altruism, courtesy, cheerleading, peacekeeping, sportsmanship, civic virtue, and conscientiousness. However, according to a meta-analysis conducted by LePine, Erez, and Johnson (2002), most of these dimensions are highly related to one another and there are no apparent differences in relationships with the most popular set of predictors. Further, managers often have difficulty distinguishing among some of these dimensions and tend to lump altruism, courtesy, cheerleading, and peacekeeping into a single 
helping behavior dimension (Bachrach, Bendoly, \& Podsakoff, 2001; MacKenzie, Podsakoff, \& Fetter, 1991, 1993; Podsakoff \& MacKenzie, 1994, 1997). Podsakoff, Whiting, Podsakoff, \& Blume (2009) suggest that helping behavior is best viewed as a second-order latent construct comprising these above four dimensions and involves behaviors that help others with workrelated problems (Podsakoff, Aherne, \& MacKenzie, 1997). Helping behavior can be defined as members' discretionary or extra role behaviors aimed at benefiting other group members or the group as a whole (Organ, Podsakoff, \& MacKenzie, 2006: p. 308; Sparrowe, Soetjipto, \& Kraimer, 2006).

It has been suggested that helping behaviors have their roots, in part, in cultural values and norms (Erez, 1997; Kwantes, 2003), and a link between culture and helping behavior has been demonstrated by a number of studies (e.g., Lin \& Ho, 2010; Moorman \& Blakely, 1995). Similarly, there has been some research to suggest that helping behavior may also be connected to gender (Eagly \& Crowley, 1986; Mann, 2007; Farrell \& Finkelstein, 2007; Heilman \& Chen, 2005). However, the claim that gender or culture will dictate helping behavior has not yielded any consistent findings. Rather than targeting culture or gender per se, we believe that the role of proportional representation of diverse social categories needs be considered in exploring the effect of group demographic diversity on helping behavior (discussed below).

Early research on work group demographic composition and individual member behavior was conducted by Kanter (1977), who was ultimately concerned with explaining specific behavioral outcomes stemming from the proportional representation of different social categories (based on race, gender etc.) in the workplace and specifically, numerical under-representation. Kanter (1977) offered valuable insights regarding the influence of demographic composition on individual behavior by attention to both the social category which an individual represents and the proportion of this social category in a group. Kanter (1977a, 1977b) asserted that when a social category (gender or culture category) has solo status in a group, several critical consequences arise. These consequences can be evident in "tilted" groups (where between $15 \%$ and $35 \%$ of the group are members of a minority social category) but are most pronounced in "skewed" groups (i.e. when a social category constitutes $15 \%$ or less of a group). These assertions have received research support (e.g., Li, Karakowsky, \& Siegel, 1999).

According to Kanter (1977), a group member who exists in the numerical minority (based on a social category) is in a position of representing their ascribed category in the group, regardless of any deliberate choice to do so, and tends to feel isolated from the numerical majority (Kanter, 1977a). These assertions are congruent with the implications of social identity theory (SIT) (Tajfel, 1982) and self-categorization theory (Turner, 1982), an extension of SIT. According to Kanter (1977), individuals in numerical minority positions possess the perception of being highly visible to the rest of the group. In other words, a group member who represents the numerical minority in a group will typically be acutely aware of this status (Taylor, Fiske, Etcoff, \& Ruderman, 1978).

Given the impact of numerical status, as indicated above, the behavior of the numerical minority is typically equated with an inhibited, passive quality (Kanter, 1977b). That is, the salience of their social category makes them feel excluded from the in-group. With regard to the variables of interest to this study, based on Kanter's (1977) assertions, those in the numerical minority in a group are less likely to exhibit helping behavior in their groups. The passive behavior commonly associated with an "outsider" or numerical minority is incongruent with demonstrations of helping behavior. In other words, for the purpose of our study, Kanter's structural approach would predict a main effect of proportional representation in the group on measures of exhibited helping behavior. In line with this reasoning, we propose that the proportional representation of social categories based on gender or culture within a team will influence levels of helping behavior exhibited by various team members.

Hypothesis 1: A team member, who has numerical minority status based on gender, will be less likely to engage in helping behavior compared to an individual who is in a numerically balanced or dominant position.

Hypothesis 2: A team member, who has numerical minority status based on culture, will be less likely to engage in helping behavior compared to an individual who is in a numerically balanced or dominant position.

\section{Method}

\section{Participants}

The hypotheses were tested via a laboratory study. Participants included 216 university students from undergraduate business programs in two large North American universities (108 men, 108 women). The average age of the participants was 20.5 years old $(\mathrm{SD}=3.99)$.

\section{Procedure}

Participants were randomly assigned to 36 groups with six members per group and were given 30 minutes to develop documented solutions for two assigned business-related cases (Karakowsky \& Siegel, 1999). Given that individuals may respond differently to gender-biased tasks (e.g., Carr, Thomas, \& Mednick, 1985; Vancouver \& Ilgen, 1989), we used two sets of tasks or cases. The two cases employed in the study, from Karakowsky \& Siegel (1999), differed in terms of their gender orientation. One case involved male-stereotyped content, the other-female-stereotyped content. Group members were randomly seated around a table (roundtable) for the duration of this discussion. The research assistant (RA) distributed the first case, allowed the group several minutes to read it, and then activated the video-recording equipment. The RA placed a pad of paper and pen in the center of the group's table, equidistant from all members. The RA then left the room for the duration of the group discussion. The video camera recorded the key event - the action of a member voluntarily taking the pen and paper in hand and becoming the "volunteer scribe" for the group. After the allotted time, the RA returned, shut off the video recorder and distributed the first set of questionnaires. The RA followed identical procedures for the second group discussion task. Once again, the video camera recorded the event of a member becoming the "volunteer scribe" for the group. To control for possible confounding effects, the order of the two types of case discussion tasks were counterbalanced, as was the use of a male or female RA in facilitating the data collection. The statistical analysis of data was conducted by using a weighted-logistic regression model in SPSS.

\section{Dependent Variable}

Helping Behavior. In this study, and consistent with previ- 
ous research, we conceptualized helping behavior as a single act. In this case, the act of volunteering to serve as the group's secretary or documenter of the group's discussion was consider to be a critical helping behavior. The RA observed the videotaped discussions and noted which individual had volunteered to act as scribe for the group's discussion.

\section{Independent Variables}

Numerical Status. This variable reflected the proportional representation in the group based on gender. Participants were randomly assigned to one of three types of mixed gender groups: Male-dominated (five men and one woman), femaledominated (five women and one man), or gender balanced (three men and three women).

Relational Demography. This variable reflected the proportional representation based on culture. The relational demography score is a measure of the difference between an individual and all other group members in terms of a specific demographic attribute. We calculated a relational demography score for each group member using Tsui et al.'s (1992) formula. An individual with a larger score differed more in terms of this characteristic from other individuals in the group than an individual with a smaller score. For the purpose of this study, we used the following item as a proxy for participant's familiarity with North American culture: "Living in North America for at least 10 years" or "Living in North America for less than 10 years". Relational demography was based on random assignment without recognition of culture a priori.

\section{Covariates/Control Variables}

Masculinity-Femininity. In addition to recording the gender of each participant, following the group's second discussion task, each participant completed the Bem Sex-Role Inventory (BSRI) (Bem, 1974). For the purpose of this study, the standardized masculinity and femininity scores were used as covariates. Given that prior research has connected these scores with intra-group behavior, we controlled for its variation across members. The Cronbach's Alpha coefficients for the masculinity and femininity measures were .87 and .77 , respectively.

Self-Efficacy in Communication. Following completion of the second discussion task, the participants completed a questionnaire which provided a self-report measure of self-efficacy with regard to the ability to communicate in a group context $(\mathrm{Li}$, Karakowsky, \& Siegel, 1999). This instrument contained eight-items scored on 7-point Likert-type scale ranging from "strongly agree" to "strongly disagree". We controlled for this because member comfort in discussion groups may have affected their willingness to engage in helping behavior. The Alpha coefficient for this measure was .86.

Prior Familiarity with Other Group Members. Following the study, participants were required to indicate whether they had known group members prior to joining the study. In analyzing the data, the Familiarity covariate was composed of three categories: No prior familiarity with any other group members; prior familiarity with one other group member; prior familiarity with two group members (no participants indicated that they were familiar with more than two other members). Once again, we felt that this factor should be controlled for since it might affect helping behavior.

Age. Following the study, participants were requested to in- dicate their age.

Location. Because participants were students from two different universities (156 participants forming 26 groups from one university, 60 participants forming 10 groups from another) it was necessary to ensure that the two sub-sets did not differ in any way that could confound the results of the study.

Other. Two other variables were included to control for possible confounds: 1) Gender of the research assistant and 2) the order in which the tasks were presented to the group, where the order of the presentation of the two cases was counterbalanced.

\section{Results}

Summaries of descriptive statistics of all the variables in this study across both the masculine and feminine-oriented tasks are presented in Tables $\mathbf{1}$ and $\mathbf{2}$.

We used a weighted-logistic regression to analyze helping behavior for each of the masculine-oriented and feminine-oriented tasks separately. The numerical status factor, due to its interpretation in the design of this experiment, resulted in fewer (24) individuals in gender-based minority positions, more (72) individuals in gender-based balanced positions, and many (120) individuals in gender-based majority positions. Logistic regression is a frequency-based procedure and, therefore, the results of an unweighted analysis would be distorted by the differences in frequencies inherent in the design. To eliminate this effect, each person in a gender minority position was assigned a weight of 15 , in a gender balanced position was assigned a weight of 5 , and in a gender majority position was assigned a weight of 3 . The assigned weights were inversely proportionate to the number of individuals in each position.

We conducted separate analyses of helping behavior for each of the two types of tasks. First, we present results with respect to the masculine-oriented task. Using a predicted probability of being a volunteer of above $50 \%$ as indicating that the model predicted that person's volunteering behavior, the model correctly predicted the volunteering status of $100 \%$ of the non-volunteers and $76 \%$ of those who had become volunteers (Table 3).

According to the results of our analysis, the gender-based numerical status of the participant (i.e., numerically balanced vs. minority; numerical majority vs. minority) had a significant influence on the likelihood of helping behavior (see Table 3). Individuals in a gender minority position were significantly less likely to volunteer as a scribe than individuals in either a gender balanced position $(\mathrm{B}=3.03, p<.01)$ or a gender majority position $(\mathrm{B}=1.74, p<.01)$. In terms of magnitude, those in a gender minority position were 23 times less likely to volunteer than were those in a gender balanced position and 61 times less likely to volunteer than those in the gender majority position. Therefore, these results provide support for Hypothesis 1 with respect to the masculine-oriented task.

Pertaining to relational demography, our results indicate that the more participants differed from their group members in terms of the length of time they lived in North America, the less likely they were to engage in helping behaviors $(\mathrm{B}=-5.45, p$ $<.01)$. In other words, a greater level of relational demography was associated with a lower likelihood of volunteering as a scribe. This result is consistent with the prediction of Hypothesis 2 , as it pertains to the masculine-oriented task.

Next, we present results with respect to the feminine-oriented task. As above, using a predicted probability of being a volunteer 


\section{KOTLYAR, L. KARAKOWSKY}

Table 1.

Summary of descriptive statistics for the observed sample on the masculine oriented task $(\mathrm{N}=216)$, (weighted $\mathrm{N}=1080)$.

\begin{tabular}{|c|c|c|c|c|c|c|c|c|c|c|c|c|c|c|c|c|c|}
\hline & \multirow[b]{2}{*}{ Variable } & \multirow[b]{2}{*}{$M$} & \multirow[b]{2}{*}{$S D$} & \multirow[b]{2}{*}{$\alpha$} & & \multicolumn{12}{|c|}{ Weighted spearman correlations } \\
\hline & & & & & & 1 & 2 & 3 & 4 & 5 & 6 & 7 & 8 & 9 & 10 & 11 & 12 \\
\hline 1 & $\begin{array}{l}\text { Citizenship } \\
\text { behavior }\end{array}$ & - & - & - & 1 & & & & & & & & & & & & \\
\hline 2 & $\begin{array}{c}\text { Gender of } \\
\text { subject }\end{array}$ & - & - & - & 2 & $.25^{* *}$ & & & & & & & & & & & \\
\hline 3 & Gender of R.A. & - & - & - & 3 & -.05 & 0 & & & & & & & & & & \\
\hline 4 & $\begin{array}{l}\text { Order of the } \\
\text { tasks }\end{array}$ & - & - & - & 4 & -.05 & 0 & 0 & & & & & & & & & \\
\hline 5 & $\begin{array}{l}\text { Numerical } \\
\text { status } \\
\text { (gender) }\end{array}$ & - & - & - & 5 & $-.2^{* *}$ & 0 & 0 & 0 & & & & & & & & \\
\hline 6 & Location & - & - & - & 6 & $-.21^{* *}$ & 0 & $.45^{* *}$ & $.33^{* *}$ & 0 & & & & & & & \\
\hline 7 & $\begin{array}{l}\text { Relational } \\
\text { demography } \\
\text { (culture) }\end{array}$ & .43 & .51 & - & 7 & $-.28^{* *}$ & $-.07^{*}$ & $.29^{* *}$ & $.34^{* *}$ & .04 & $.65^{* *}$ & & & & & & \\
\hline 8 & Age & 23.9 & 7.22 & - & 8 & $-.24^{* *}$ & $.07^{*}$ & -.03 & $.08^{*}$ & $.19^{* *}$ & $.24^{* *}$ & $.2^{* *}$ & & & & & \\
\hline 9 & $\begin{array}{l}\text { One friend in } \\
\text { the group }\end{array}$ & .09 & .28 & - & 9 & .04 & $-.18^{* *}$ & $.13^{* *}$ & $.29^{* *}$ & .01 & $-.16^{* *}$ & .01 & $-.2^{* *}$ & & & & \\
\hline 10 & $\begin{array}{l}\text { Two friends in } \\
\text { the group }\end{array}$ & .06 & .24 & - & 10 & $.09^{* *}$ & $-.12^{* *}$ & -.05 & .05 & $.18^{* *}$ & $-.3^{* *}$ & $.07^{*}$ & $-.26^{* *}$ & $.12^{* *}$ & & & \\
\hline 11 & $\begin{array}{l}\text { Self-efficacy in } \\
\text { communication }\end{array}$ & 42.87 & 9.06 & .86 & 11 & $.09^{* *}$ & $-.27^{* *}$ & $-.26^{* *}$ & .05 & $-.25^{* *}$ & $-.17^{* *}$ & $.11^{* *}$ & $-.08^{*}$ & $-.16^{* *}$ & $.2^{* *}$ & & \\
\hline 12 & $\begin{array}{l}\text { Bem-masc. } \\
\text { score }\end{array}$ & 50.52 & 11.2 & .87 & 12 & .03 & $-.46^{* *}$ & $-.18^{* *}$ & $-.21^{* *}$ & $-.17^{* *}$ & $-.43^{* *}$ & $-.29^{* *}$ & $-.31^{* *}$ & .04 & .04 & $.56^{* *}$ & \\
\hline 13 & Bem-fem. score & 48.53 & 10.39 & .77 & 13 & $.4^{* *}$ & $.49^{* *}$ & $-.21^{* *}$ & $.13^{* *}$ & $-.08^{*}$ & $-.25^{* *}$ & $-.21^{* *}$ & $-.16^{* *}$ & $-.24^{* *}$ & $.2^{* *}$ & $.23^{* *}$ & $-.13^{* *}$ \\
\hline
\end{tabular}

Note: $M, S D$, and $\alpha$ are unweighted. ${ }^{*} p<.05 ;{ }^{* *} p<.01$

Table 2.

Summary of descriptive statistics for the observed sample on the feminine oriented task $(\mathrm{N}=216),($ weighted $\mathrm{N}=1080)$.

\begin{tabular}{|c|c|c|c|c|c|c|c|c|c|c|c|c|c|c|c|c|c|}
\hline & \multirow[b]{2}{*}{ Variable } & \multirow[b]{2}{*}{$M$} & \multirow[b]{2}{*}{$S D$} & \multirow[b]{2}{*}{$\alpha$} & & \multicolumn{12}{|c|}{ Weighted spearman correlations } \\
\hline & & & & & & 1 & 2 & 3 & 4 & 5 & 6 & 7 & 8 & 9 & 10 & 11 & 12 \\
\hline 1 & $\begin{array}{c}\text { Citizenshi } \\
\text { behavior }\end{array}$ & - & - & - & 1 & & & & & & & & & & & & \\
\hline 2 & $\begin{array}{c}\text { Gender of } \\
\text { subject }\end{array}$ & - & - & - & 2 & $.28^{* *}$ & & & & & & & & & & & \\
\hline 3 & $\begin{array}{l}\text { Gender of } \\
\text { R.A. }\end{array}$ & - & - & - & 3 & -.03 & 0 & & & & & & & & & & \\
\hline 4 & $\begin{array}{l}\text { Order of the } \\
\text { tasks }\end{array}$ & - & - & - & 4 & $.08^{* *}$ & 0 & 0 & & & & & & & & & \\
\hline 5 & $\begin{array}{l}\text { Numerical } \\
\text { status } \\
\text { (gender) }\end{array}$ & - & - & - & 5 & $-.15^{* *}$ & 0 & 0 & 0 & & & & & & & & \\
\hline 6 & Location & - & - & - & 6 & $-.11^{* *}$ & .01 & $.47^{* *}$ & $.34^{* *}$ & .01 & & & & & & & \\
\hline 7 & $\begin{array}{l}\text { Relational } \\
\text { demography } \\
\text { (culture) }\end{array}$ & .43 & .51 & - & 7 & -.04 & -.05 & $.24^{* *}$ & $.36^{* *}$ & .04 & $.66^{* *}$ & & & & & & \\
\hline 8 & Age & 23.9 & 7.22 & - & 8 & $-.35^{* *}$ & .05 & .01 & .03 & $.14^{* *}$ & $.26^{* *}$ & $.21^{* *}$ & & & & & \\
\hline 9 & $\begin{array}{l}\text { One friend in } \\
\text { the group }\end{array}$ & .09 & .28 & - & 9 & $.28^{* *}$ & $-.16^{* *}$ & $.22^{* *}$ & $.22^{* *}$ & $-.08^{* *}$ & $-.13^{* *}$ & $-.14^{* *}$ & $-.11^{* *}$ & & & & \\
\hline 10 & $\begin{array}{l}\text { Two friends } \\
\text { in the group }\end{array}$ & .06 & .24 & - & 10 & .05 & $-.1^{* *}$ & $-.09^{* *}$ & $.09^{* *}$ & $.15^{* *}$ & $-.31^{* *}$ & $.12^{* *}$ & $-.33^{* *}$ & $.11^{* *}$ & & & \\
\hline 11 & $\begin{array}{l}\text { Self-efficacy } \\
\text { in } \\
\text { comunication }\end{array}$ & 42.87 & 9.06 & .86 & 11 & $.26^{* *}$ & $-.25^{* *}$ & $-.2^{* *}$ & .03 & $-.23^{* *}$ & $-.28^{* *}$ & $.07^{*}$ & $-.17^{* *}$ & 0 & $.25^{* *}$ & & \\
\hline 12 & $\begin{array}{l}\text { Bem-masc. } \\
\text { score }\end{array}$ & 50.52 & 11.2 & .87 & 12 & .05 & $-.44^{* *}$ & $-.16^{* *}$ & $-.25^{* *}$ & $-.19^{* *}$ & $-.36^{* *}$ & $-.26^{* *}$ & $-.25^{* *}$ & $.06^{*}$ & -.04 & $.59^{* *}$ & \\
\hline 13 & $\begin{array}{l}\text { Bem-fem. } \\
\text { score }\end{array}$ & 48.53 & 10.39 & .77 & 13 & $.45^{* *}$ & $.62^{* *}$ & $-.15^{* *}$ & $.09^{* *}$ & $-.15^{* *}$ & $-.32^{* *}$ & $-.11^{* *}$ & $-.37^{* *}$ & .02 & $.24^{* *}$ & $.17^{* *}$ & $-.12^{* *}$ \\
\hline
\end{tabular}

Note: $M, S D$, and $\alpha$ are unweighted. ${ }^{*} p<.05 ;{ }^{* *} p<.01$. 
Table 3.

Summary of weighted logistic regression analysis of characteristics influencing the likelihood of citizenship behavior in the case of the masculine oriented task

\begin{tabular}{cc}
\hline Variable & $\mathrm{B}(\mathrm{SE})$ \\
\hline Location & $6.12^{* *}(.85)$ \\
One friend in group & $-.12^{* *}(.03)$ \\
Two friends in group & $5.49^{* *}(.78)$ \\
Self-efficacy in communication & $6.24^{* *}(1.24)$ \\
Bem-masculine score & $-.10^{*}(.05)$ \\
Bem-feminine score & $.22^{* *}(.04)$ \\
Gender of subject & $.31^{* *}(.04)$ \\
Gender of RA & $-1.86^{* *}(.40)$ \\
Order of the tasks & $.87^{* *}(.28)$ \\
Relational demography (culture) & $1.73^{* *}(.31)$ \\
Numerical status (gender balanced vs. gender & $-5.45^{* *}(.73)$ \\
minority) & $3.03^{* *}(.50)$ \\
Numerical status (gender majority vs. gender & $1.74^{* *}(.48)$ \\
\hline minority) &
\end{tabular}

Note: ${ }^{*} p<.05 ;{ }^{* *} p<.01$.

of above $50 \%$ as indicating that the model predicted a person's volunteering behavior, the model correctly predicted the volunteering status of $100 \%$ of the time for non-volunteers and $81 \%$ of those who had volunteered (Table 4).

Again, the numerical status based on gender had a significant effect on helping behavior of participants. Group members in gender minority positions were less likely to engage in helping behavior compared to members in balanced $(\mathrm{B}=2.42, p<.01)$ or majority positions $(\mathrm{B}=2.41, p<.01)$. These results provide support for Hypothesis 1.

Increases in relational demography tended to decrease the likelihood of becoming a volunteer $(\mathrm{B}=-1.75, p<.01)$. Once again, this finding is consistent with the assertion of Hypothesis 2. All other influences were by control factors and, therefore, not of direct interest in this study.

\section{Discussion and Summary}

Our paper attempts to move the organizational citizenship behavior research forward by considering that gender or ethnicity alone does not necessarily predict levels of helping behavior. Rather, we need to view helping behavior within the larger social context. This demands we recognize the impact of proportional representation of diverse social categories. Being in the perceived minority position can have a damaging impact on helping behavior. If a group member feels isolated from the majority (like the proverbial "fish out of water"), this might inhibit behaviors commonly associated with helping behavior. A consideration of Kanter's (1977) view of proportional representation suggests that perceptions of influence are affected by the numerical presence of different social categories. Such situations of tokenism enhance the visibility of the token and
Table 4.

Summary of hierarchical weighted logistic regression analysis of characteristics influencing the likelihood of citizenship behavior in the case of the female oriented task.

\begin{tabular}{cc}
\hline Variable & B (SE) \\
\hline Location & $2.59^{* *}(.66)$ \\
Age & $-.28^{* *}(.05)$ \\
One friend in group & $9.11^{* *}(1.02)$ \\
Two friends in group & $-6.03^{* *}(1.42)$ \\
Self-efficacy in communication & $.29^{*}(.04)$ \\
Bem-masculine score & $-.03(.03)$ \\
Bem-feminine score & $.30^{* *}(.05)$ \\
Gender of subject & $-.83^{*}(.39)$ \\
Gender of RA & $.49(.26)$ \\
Order of the tasks & $1.63^{* *}(.29)$ \\
Relational demography (culture) & $-1.75^{* *}(.64)$ \\
Numerical status (gender balanced vs. gender & $2.42^{* *}(.46)$ \\
minority) & $2.41^{* *}(.49)$ \\
Numerical status (gender majority vs. gender & minority)
\end{tabular}

Note: ${ }^{*} p<.05 ;{ }^{*} p<.01$.

may inhibit helping behavior.

Our study suggests that being in the perceived minority position can have a damaging impact on helping behavior. This makes intuitive sense. If one feels isolated from the majority, this might inhibit behaviors commonly associated with helping behavior. Our study underscores the necessity of integrating an understanding of the dynamics of proportional representation into studies that endeavor to measure helping behavior in diverse populations.

There are a number of limitations regarding our research design as well as a number of questions that remained unanswered by our study. First, the issue of generalizability must be considered. The use of a university student sample and the shortterm duration of the work groups under examination place limits on the degree to which we can generalize our findings to the workplace. Second, the experimental design employed in this study could not avoid the problem of lack of independence among subjects. Specifically, the behavior of a target subject clearly can be influenced by the behavior of their group members. Consequently, one member's helping behavior, for example, is partly a function of the other members' lack of involvement. This violates the assumption of independence implicit in the statistical analyses (c.f., Raudenbush, 1997). Third, while this study attempted to control for a number of individual differences such as masculinity-femininity and self-efficacy, it would be of interest to consider the effects of other pertinent characteristics including extroversion-introversion as measured by the Myers-Briggs Type Indicator (MBTI) (Myers \& McCaully, 1985) with regard to helping behavior. In addition, while the measure used to assess gender roles, Bem's Sex-role Inventory (Bem, 1974, 1993), has been widely employed, the research has offered evidence that traditional masculine and 
feminine gender role perceptions may be weakening (c.f., Holt $\&$ Ellis, 1998). Consequently, what constitutes the most appropriate measure of gender roles needs to be continually reevaluated.

In practical terms, this paper's message is important for managers - employees that are in a numerical minority position may not feel fully prepared to engage in helping behavior for a variety of reasons. At one level, it could simply be inhibitions experienced that prevent the employee from "going out on a limb" to display behavior that is more typically associated with a numerical majority member. The experience of tokenism can lead a member to feel somewhat incapable of engaging in meaningful or valued helping behavior. The need to develop "team players" requires an intimate understanding of how the mix of diverse members in a team context will influence member behaviors and potentially inhibit helping behavior if not managed properly.

Our study raises an important cautionary note for managers and for any individual that functions in a team. An individual who is cast in a numerical minority role may in fact be inhibited from performing a variety of group roles. While the impact on performance has been debated, the phenomenon of helping behavior may be subject to different dynamics - particularly because it is not a formally mandated expectation of the group - it has a voluntary dimension. Lone women performers in teams may overcome the inhibitions of minority status in order to perform successfully in her group. However, will those relegated to numerical minority positions also feel comfortable to go above and beyond performance expectations and engage in voluntary citizenship behaviors? What is striking in our study is that the results suggest that numerical minority status (based on both gender and culture) can inhibit such behavior. Such impediments could become a self-fulfilling prophecy-with the numerical minority member feeling and acting like an outsider. Given the impression management aspect of helping behavior this could also further undermine chances for member achievement or reward in the group.

This paper underscores the need to more fully consider what can be done at the group level to facilitate the effective integration of diverse team members in order to maximize the effecttiveness of team decision-making. How team members feel about their ability to contribute to the overall well-being of the group has critical implications for helping behavior. Consequently, it is critical to identify those factors that can influence perceptions of member identity and comfort in the group. This study suggests that without consciously managing team diversity, numerically under-represented groups members may be potentially inhibited from engaging in extra role behavior.

If the aim of a work team is to increase member involvement, then our paper begs the question-what technique(s) might minimize the detrimental effects of variations in imputed expertise and numerical minority status? It certainly appears critical to engage in team activities that minimize any feelings of in group out-group perceptions among team members. Involvement in team performance will spill over to extra role behavior, so activities that ensure ample participation among all members will be fruitful. For example, previous research has suggested that designating a group member as facilitator or gate-keeper in group discussions could help ensure that all group members are encouraged to contribute their ideas (Keltner, 1989). The use of facilitation to enhance group work is not a new concept, and has proven to be a productive technique in a range of areas such as group brainstorming (e.g., Keltner, 1989). Consistent with Karakowsky, Mann and McBey's (2010), in order to assist the integration of members within diverse work teams, the research should continue to consider what methods or techniques can enhance member involvement in group activity (both in role and extra role) and what factors encourage members to generate positive perceptions regarding the value of their contributions to the group. In light of the rapidly growing diverse workforce, more research should quickly address this critical issue.

\section{REFERENCES}

Allen, T. D., \& Rush, M. C. (2001). The influence of rate gender on organizational helping behavior. Journal of Applied Social Psychology, 31, 2561-2587. doi:10.1111/j.1559-1816.2001.tb00191.x

Bachrach, D. G., Bendoly, E., \& Podsakoff, P. M. (2001). Attributions of the "causes" of group performance as an alternative explanation of the relationship between organizational citizenship behavior and organizational performance. Journal of Applied Psychology, 86, 12851293. doi:10.1037/0021-9010.86.6.1285

Belansky, E. S., \& Boggiano, A. K. (1994). Predicting helping behaviors: The role of gender and instrumental/expressive self-schemata. Sex Roles, 30, 647-661. doi:10.1007/BF01544668

Bem, S. L. (1993). The lenses of gender. New Haven, CT: Yale University Press.

Bem, S. (1974). The measurement of psychological androgyny. Journal of Consulting and Clinical Psychology, 42, 155-162. doi: $10.1037 / \mathrm{h} 0036215$

Blakely, G. L., Srivastava, A. \& Moorman, R. H. (2005). The effects of nationality, work role centrality and work locus of control on role definitions of OCB. Journal of Leadership and Organizational Studies, 12, 103-117. doi:10.1177/107179190501200109

Bowes-Sperry, L., Veiga, J. F., \& Yanouzas, J. N. (1997). An analysis of managerial helping responses based on social role theory. Group \& Organization Studies, 22, 445-459. doi: $10.1177 / 1059601197224003$

Carr, P. G., Thomas, V. G., \& Mednick, M. T. (1985). Evaluation of sex-typed tasks by black men and women. Sex Roles, 13, 311-316. doi:10.1007/BF00288087

Carbaugh, D. (1996). Situating selves: The communication of social identities in American scenes. Albany, NY: State University of New York Press.

Choi, J. N. (2009). Collective dynamics of citizenship behaviour: What group characteristics promote group-level helping? Journal of Management Studies, 46, 1396-1420. doi:10.1111/j.1467-6486.2009.00851.X

Chou, S. Y., \& Pearson, J. (2011). A demographic study of information technology professionals organizational citizenship behavior. Journal of Management Research, 3, 1-15. doi:10.5296/jmr.v3i2.625

Coon, H. M. \& Kemmelmeier, M. (2001). Cultural orientations in the United States: Re-examining differences among ethnic groups. Journal of Cross-Cultural Psychology, 32, 348-364. doi: $10.1177 / 0022022101032003006$

Danzis, D. A., \& Stone-Romero, E. (2009). Effects of helper sex, recipient attractiveness, and recipient femininity on helping behavior in organizations. Journal of Managerial Psychology, 24, 722-737. doi:10.1108/02683940910996761

Davis, P. S., Babakus, E., Englis, P. D., \& Pett, T. (2010). The influence of CEO gender on market orientation and performance in service small and medium-sized service businesses. Journal of Small Business Management, 48, 475-496. doi:10.1111/j.1540-627X.2010.00305.x

Dovidio, J., Brown, C., Ellyson, S., Keating, C., \& Heltman, K. (1988). The relationship of social power to visual displays of dominance between men and women. Journal of Personality and Social Psychology, 54, 233-242. doi:10.1037/0022-3514.54.2.233

Eagly, A. H. (1983). Gender and social influence: A social psychological analysis. American Psychologist, 38, 971-981. 
doi:10.1037/0003-066X.38.9.971

Eagly, A. H., \& Crowley, M. (1986). Gender and helping behavior: A meta-analytic review of the social psychological literature. Psychological Bulletin, 100, 283-308. doi:10.1037/0033-2909.100.3.283

Erez, M. (1997). A culture based model of work motivation. In P. C. Earley \& M. Erez (Eds.), New perspectives on international industrial/organizational psychology (pp. 193-242). San Francisco, CA: Jossey-Bass.

Farrell, S. K., \& Finkelstein, L. M. (2007). Organizational citizenship behavior and gender: Expectations and attributions for performance. North American Journal of Psychology, 9, 81-95.

George, J. M. \& Bettenhausen, K. (1990). Understanding prosocial behavior, sales performance, and turnover: A group-level analysis in a service context. Journal of Applied Psychology, 75, 698-709. doi:10.1037/0021-9010.75.6.698

George, D., Carroll, P., Kersnick, R., \& Calderon, K. (1998). Genderrelated patterns of helping among friends. Psychology of Women Quarterly, 22, 685-704. doi:10.1111/j.1471-6402.1998.tb00185.x

Gilbert, G. R., Burnett, M. F., Phau, I., \& Haar, J. (2010). Does gender matter? A review of work-related gender commonalities. Gender in Management, 25, 676-699. doi:10.1108/17542411011092336

Graves, L. M., \& Elsass, P. M. (2005). Sex and sex dissimilarity effects in ongoing teams: Some surprising findings. Human Relations, 58, 191-221. doi:10.1177/0018726705052181

Grob, L. M., Meyers, R. A., \& Schuh, R. (1997). Powerful/powerless language use in group interactions: Sex differences or similarities? Communication Quarterly, 45, 282-304. doi: $10.1080 / 01463379709370066$

Heilman, M. E., \& Chen, J. J. (2005). Same behavior, different consequences: Reactions to mens and womens altruistic citizenship behavior. Journal of Applied Psychology, 90, 431-441. doi:10.1037/0021-9010.90.3.431

Hinkle, S., \& Brown, R. J. (1990). Intergroup comparisons and social identity. In D. Abrams, \& M. A. Hogg (Eds.), Social identity theory: Constructive and critical advances (pp. 48-70). New York: SpringerVerlag.

Holland, S., Gaston, K., \& Gomes, J. (2000). Critical success factors for cross-functional teamwork in the new product development. International Journal of Management Reviews, 2, 231-259. doi:10.1111/1468-2370.00040

Holt, C. L., \& Ellis, J. B. (1998). Assessing the current validity of the Bem sex-role inventory. Sex Roles, 39, 929-941. doi:10.1023/A:1018836923919

Hood, J. N., \& Koberg, C. S. (1994). Patterns of differential assimilation and acculturation for women in business organizations. Human Relations, 47, 159-159. doi:10.1177/001872679404700202

Johnson, R. A., \& Schulman, G. I. (1989). Gender-role composition and role-entrapment in decision-making groups. Gender \& Society, 3, 353-372. doi: $10.1177 / 089124389003003005$

Jones, J. R. \& Schaubroeck, J. (2004). Mediators of the relationship between race and organizational citizenship behavior. Journal of Managerial Issues, 16, 505-527.

Kanter, R. M. (1977a). Some effects of proportions in group life: Skewed sex ratios and responses to numerical minority women. American Journal of Sociology, 82, 965-990. doi:10.1086/226425

Kanter, R. M. (1977b). Men and women of the corporation. New York: Basic Books.

Kanter, R. M. (1980). A tale of “O”. New York: Harper \& Row Publishers.

Karakowsky, L., Mann, S., \& McBey, K. (2010). Feeling (and acting) like a fish out of water: Numerical minority status, gendered work and citizenship behavior in mixed gender work teams. Team Performance Management, 16, 413-430. doi:10.1108/13527591011090664

Karakowsky, L., McBey, K., \& Miller, D. L. (2004). Gender, perceived competence, and power displays. Small Group Research, 35, 407439. doi:10.1177/1046496404263728

Karakowsky, L., \& Siegel, J. P. (1999). The effects of proportional representation and gender-orientation of the task on emergent leadership behavior in mixed-gender groups. Journal of Applied Psychology, 84, 620-631. doi:10.1037/0021-9010.84.4.620
Kidder, D., \& Judi McLean Parks (2001). The good soldier: Who is $\mathrm{s}(\mathrm{he})$ ? Journal of Organizational Behavior, 22, 939-959. doi:10.1002/job.119

Kirkman, B. L., Tesluk, P. E., \& Rosen, B. (2004). The impact of demographic heterogeneity and team leader-team member demographic fit on team empowerment and effectiveness. Group \& Organization Management, 29, 334-368. doi: $10.1177 / 1059601103257412$

Kwantes, C. T. (2003). Organizational citizenship and withdrawal behaviors in the USA and India: Does commitment make a difference? Cross Cultural Management, 3, 5-26. doi: $10.1177 / 1470595803003001847$

Lam, S. S. K., Hui, C., \& Law, K. S. (1999). Organizational citizenship behavior: Comparing perspectives of supervisors and subordinates across four international samples. Journal of Applied Psychology, 84, 594. doi:10.1037/0021-9010.84.4.594

Lauring, J., \& Selmer, J. (2011). Multicultural organizations: Common language, knowledge sharing and performance. Personnel Review, 40, 324-343. doi:10.1108/00483481111118649

Lenartowicz, T. \& Roth, K. (2001). Does subculture within a country matter? A cross cultural study of motivational domains and business performance in Brazil. Journal of International Business Studies, 32, 305-326. doi:10.1057/palgrave.jibs.8490954

LePine, J. A., Erez, A., \& Johnson, D. E. (2002). The nature and dimensionality of organizational citizenship behavior: A critical review and meta-analysis. Journal of Applied Psychology, 87, 52-65. doi:10.1037/0021-9010.87.1.52

Li, J., Karakowsky, L. \& Siegel, J. P. (1999). The effects of proportional representation on intragroup behavior in mixed-race decision-making groups. Small Group Research, 30, 259-279. doi:10.1177/104649649903000301

Lin, L., \& Ho, Y. (2010). Guanxi and OCB: The Chinese cases. Journal of Business Ethics, 96, 285-298. doi:10.1007/s10551-010-0465-6

MacKenzie, S. B., Podsakoff, P. M., \& Fetter, R. (1991). Organizational citizenship behavior and objective productivity as determinants of managerial evaluations of salespersons performance. Organizational Behavior and Human Decision Processes, 50, 123-123. doi:10.1016/0749-5978(91)90037-T

MacKenzie, S. B., Podsakoff, P. M., \& Fetter, R. (1993). The impact of organizational citizenship behavior on evaluations of salesperson performance. Journal of Marketing, 57, 70-70. doi:10.2307/1252058

Mahadeo, J. D., Soobaroyen, T., \& Hanuman, V. O. (2012). Board composition and financial performance: Uncovering the effects of diversity in an emerging economy. Journal of Business Ethics, 105, 375-388. doi:10.1007/s10551-011-0973-Z

Mann, S. L. (2007). Values as incremental predictors of organizational citizenship behavior. Unpublished Doctoral Dissertation, Toronto: Rotman School of Management, University of Toronto.

Moorman, R. H., \& Blakely, G. L. (1995). Individualism-collectivism as an individual difference predictor of organizational citizenship behavior. Journal of Organizational Behavior, 16, 127-142. doi:10.1002/job.4030160204

Myers, I. B., \& McCaulley M. H. (1985). Manual: A guide to the development and use of the Myers-Briggs type indicator. Palo Alto, CA: Consulting Psychologists Press.

Organ, D. W. (1988). Organizational citizenship behavior: The good soldier syndrome. Lexington, MA: Lexington Books.

Organ, D. W. (1990). The motivational basis of organizational citizenship behavior. In B. M. Staw, \& L. L. Cummings (Eds.), Research in organizational behavior (pp. 43-72). Greenwich, CT: JAI Press.

Organ, D. W., \& Konovsky, M. (1989). Cognitive versus affective determinants of organizational citizenship behavior. Journal of Applied Psychology, 74, 157-164. doi:10.1037/0021-9010.74.1.157

Organ, D. W., Possakoff, P. M., \& MacKenzie, S. B. (2006). Organizational citizenship behavior: Its nature, antecedents and consequences. Thousand Oaks, CA: Sage.

Organ, D. W., \& Ryan, K. (1995). A meta-analytic review of attitudinal and dispositional predictors of organizational citizenship behavior. Personnel Psychology, 48, 775-802.

doi:10.1111/j.1744-6570.1995.tb01781.x

Paine, J. B., \& Organ, D. W. (2000). The cultural matrix of organiza- 


\section{KOTLYAR, L. KARAKOWSKY}

tional citizenship behavior: Some preliminary conceptual and empirical observations. Human Resources Management Review, 10, 45-59. doi:10.1016/S1053-4822(99)00038-8

Pelled, L. H. (1996). Relational demography and perceptions of group conflict and performance: A field investigation. The International Journal of Conflict Management, 7, 230-246. doi:10.1108/eb022783

Podsakoff, P. M., Ahearne, M., \& MacKenzie, S. B. (1997). Organizational citizenship behavior and the quantity and quality of work group performance. Journal of Applied Psychology, 82, 262-270.

Podsakoff, P. M., \& MacKenzie, S. B. (1994). The impact of organizational citizenship behavior on evaluations of sales person performance. Journal of Marketing, 57, 70-81.

Podsakoff, P. M., \& MacKenzie, S. B. (1994). Organizational citizenship behaviors and sales unit effectiveness. Journal of Marketing Research, 31, 351-363. doi:10.2307/3152222

Podsakoff, P. M., \& MacKenzie, S. B. (1997). Impact of organizational citizenship behavior on organizational performance: A review and suggestions for future research. Human Performance, 10, 133-151. doi:10.1207/s15327043hup1002 5

Podsakoff, P. M., MacKenzie, S. B., Paine, J. B., \& Bachrach, D. G. (2000). Organizational citizenship behaviors: A critical review of the theoretical and empirical literature and suggestions for future research. Journal of Management, 26, 513-563. doi:10.1177/014920630002600307

Podsakoff, N. P., Whiting, S. W., Podsakoff, P. M., \& Blume, B. D. (2009). Individual-and organizational-level consequences of organizational citizenship behaviors: A meta-analysis. Journal of Applied Psychology, 94, 122. doi:10.1037/a0013079

Pratt, M. B. (1998). To be or not to be: Central questions in organizational identification. In D. A. Whetten, \& P. C. Godfrey (Eds.), Identity in organizations (pp. 171-208). Thousand Oaks, CA: SAGE.

Reskin, B. F, McBrier, D. B, \& Kmec, J. A. (1999). The determinants and consequences of workplace sex and race composition. Annual Review of Sociology, 25, 335-361. doi:10.1146/annurev.soc.25.1.335

Raudenbush, S. W. (1997). Statistical analysis and optimal design for cluster randomized trials, Psychological Methods, 2, 173-185. doi:10.1037/1082-989X.2.2.173

Ridgeway, C. L., \& Smith-Lovin, L. (1999). The gender system in interaction. Annual Review of Sociology, 25, 191-216. doi:10.1146/annurev.soc.25.1.191

Sparrowe, R. T., Soetjipto, B. W., \& Kraimer, M. (2006). Do leaders influence tactics relate to members helping behavior? It depends on the quality of the relationship. Academy of Management Journal, 49, 1194-1208. doi:10.5465/AMJ.2006.23478645

Steers, R. M., \& Sanchez-Runde, C. J. (2002). Culture, motivation, and work behavior. In M. J. Gannon, \& K. L. Newman (Eds.), The blackwell handbook of principles of cross-cultural management (pp. 190-216). Bodmin, UK: MPG Books.

Tajfel, H. (1982). Social identity and intergroup relations. Cambridge: Cambridge University Press.

Taylor, S. E., Fiske, T. F, Etcoff, N. L., \& Ruderman, A. J. (1978). Categorical and contextual bases of person memory and stereotyping. Journal of Personality and Social Psychology, 36(7), 778-793. doi:10.1037/0022-3514.36.7.778

Tsui, A. S., Egan, T. D., \& O’Reilly, C. A. (1992). Being different: Relational demography and organizational attachment. Administrative Science Quarterly, 37, 549-579. doi:10.2307/2393472

Turner, J. (1982). Toward a cognitive definition of the group. In H. Tajfel (Ed.), Social Identity and Intergroup Relations. Cambridge: Cambridge University Press.

Van der Vegt, G. S., \& Van de Vliert, E. (2005). Effects of perceived skill dissimilarity and task interdependence on helping in work teams. Journal of Management, 31, 73-89. doi:10.1177/0149206304271382

Van Dyne, L., Graham, J. W., \& Dienesch, R. M. (1994). Organizational citizenship behavior: Construct redefinition, measurement and validation. Academy of Management Journal, 37, 765-802. doi: $10.2307 / 256600$

Van Dyne, L., Vadewalle, D., Kostova, T., Latham, M. E., \& Cummings, L. L. (2000). Collectivism, propensity to trust and self-esteem as predictors of organizational citizenship behavior in a non-work setting. Journal of Organizational Behavior, 21, 3-23. doi:10.1002/(SICI)1099-1379(200002)21:1<3::AID-JOB47>3.0.CO; $\underline{2-6}$

Vancouver, J. B., \& Ilgen, D. R. (1989). Effects of interpersonal orientation and the sex-type of the task on choosing to work alone or in groups. Journal of Applied Psychology, 74, 927-934. doi:10.1037/0021-9010.74.6.927

Williams, C. L. (1992). The glass escalator: Hidden advantages for men in the female professions. Social Problems, 39, 253-267. doi: $10.2307 / 3096961$

Wood, W., \& Karten, S. J. (1986). Sex differences in interaction style as a product of perceived sex differences in competence. Journal of Personality and Social Psychology, 5, 341-347. doi: $10.1037 / 0022-3514.50 .2 .341$ 